\title{
ANTINOCICEPTIVE EFFECTS OF VALERIANA EXTRACT IN MICE: INVOLVEMENT OF THE DOPAMINERGIC AND SEROTONERGIC SYSTEMS
}

\author{
Received June 26, 2013.
}

Valeriana officinalis has been extensively used as a herbal remedy in traditional medicine. However, there is no clear evidence on the antinociceptive effects of this plant. The aim of our study was to evaluate the effect of Valeriana officinalis hydroalcoholic extract on pain modulation and its possible mechanism in mice. Adult male Balb/c mice were randomly divided into nine experimental groups. They received i.p. injections of saline, hydroalcoholic root extract of Valeriana officinalis $(800,200$, or $50 \mathrm{mg} / \mathrm{kg})$, and morphine; four groups received Valeriana $(800 \mathrm{mg} / \mathrm{kg})+$ antagonists of the systems involved in antinociception effects, naloxone, ondansetron, metoclopramide, or scopolamine. Tail-flick and writhing tests were used for estimation of possible modulation of pain. The tail-flick latencies in the Valeriana 800 and $200 \mathrm{mg} / \mathrm{kg}$, but not $50 \mathrm{mg} / \mathrm{kg}$, morphine, and combined Valeriana $800+$ + naloxone, ondansetron, metoclopramide, or scopolamine-treated groups were significantly longer than that in the control group. However, the tail-flick latencies in the Valeriana 800 $\mathrm{mg} / \mathrm{kg}$ + ondansetron- and metoclopramide-treated groups were significantly shorter than that upon single action of the extract $(800 \mathrm{mg} / \mathrm{kg})$. The numbers of writhings in the extract-treated groups were smaller than in the control one. The numbers of writhings in the Valeriana $(800 \mathrm{mg} / \mathrm{kg})+$ ondansetron- and metoclopramide-treated groups were significantly greater than in the extract $(800 \mathrm{mg} / \mathrm{kg})$ group. It is concluded that Valeriana officinalis extract possesses a clear analgesic effect and works through the serotonergic and dopaminergic systems.

Keywords: Valeriana officinalis, tail-flick test, writhing test, flavonoids, pain, mice.

\section{INTRODUCTION}

In recent years, there has been significant scientific progress in the neurobiology of pain control and introduction of the respective modern technologies. Nonetheless, we still need new analgesic drugs with better efficacy and lesser side effects. There are several approaches allowing us to use metabolites and compounds derived from known and novel plants to make these drugs [1].

Valeriana officinalis is a well-known plant growing wild in America and Eurasia [2] and commonly used in traditional medicine [3]. According to many studies, Valeriana possesses sedative, anxiolytic, tranquilizing, spasmolytic, and anticonvulsant effects [4-8]. The practical lack of side effects and low price are features that make Valeriana so common [9]. Valeriana, when

\footnotetext{
${ }^{1}$ Neurophysiology Research Center, Hamadan University of Medical Sciences, Hamadan, Iran.

${ }^{2}$ School of Medicine, Hamadan University of Medical Sciences, Hamadan, Iran.

Correspondence should be addressed to P. Pahlevani

(e-mail: pouyan.pahlevani@gmail.com).
}

producing hypolocomotor and axiolytic-like effects in rats, did not alter oxidative stress parameters in the CNS, liver, and kidneys [10].

Alkaloids, lignan, flavonoids, GABA, and valerenic acid are active compounds found in Valeriana officinalis extracts $[6,11,12]$. According to a few investigations, flavonoids exert antinociceptic effects, and Valeriana alkaloids are also members of the analgesic complement family $[1,13,14]$. As we see, Valeriana has a number of positive effects on the nervous system, but there are no direct studies related to possible antinociceptive effects of this remedy. The aim of our study was to estimate the analgesic activity of different doses of the extract from this plant and also to discover possible mechanisms underlying its action.

\section{METHODS}

Animals. Adult male Balb/c mice weighing 25-35 g were obtained from the Iran Pasteur Institute, Tehran. They were kept at a constant temperature of $22 \pm 2^{\circ} \mathrm{C}$ with a 12/12-h light/dark cycle (lights on at 7:00 a.m). Food and 
water were available ad libitum in the home cages. The animals were acclimated to the environment for 1 week before the experimental procedure. All procedures and experiments were performed between 10:00 and 14:00.

Herbal Material and Extraction. Dried roots of Valeriana officinalis were purchased from the Herbal Medicine Research Center in Hamadan, Iran. The ground material was immersed in $70 \%$ ethanol for $72 \mathrm{~h}$ at room temperature. The extract was filtered and then freezer-dried.

Tail-Flick Test. A tail-flick apparatus for mice was used to produce radiant heat on the mouse tail (about $3 \mathrm{~cm}$ from the tip). The heat intensity was adjusted such that the mean tail-flick latency (TFL) was about $3 \mathrm{sec}$, and a maximum cut-off time of $8 \mathrm{sec}$ was set to avoid tissue damage. Mice were randomly divided into nine groups ( $n=8$ each). These groups received saline (control group), dry Valeriana extract $(800,200$, or $50 \mathrm{mg} / \mathrm{kg})$ dissolved in saline, morphine $(1 \mathrm{mg} / \mathrm{kg}$; positive antinociception control group), and co-administrations of Valeriana $(800 \mathrm{mg} / \mathrm{kg}$ ) with naloxone (a blocker of opioid receptors, $4 \mathrm{mg} / \mathrm{kg}$ ), ondansetron (an antagonist of the serotonergic system, $0.5 \mathrm{mg} / \mathrm{kg}$ ), metoclopramide (an antagonist of the dopaminergic system, $1 \mathrm{mg} / \mathrm{kg}$ ), or scopolamine (an antagonist of muscarinic cholinoreceptors, $1 \mathrm{mg} / \mathrm{kg}$ ). Three tail-flick trials (with 1-min-long intertrial intervals) were performed before and after drug administration. The TLF for each rat was calculated as the average of three consecutive measurements.

Acetic Acid Writhing Test. This test is based on chemical induction of visceral pain. Acetic acid $(0.6 \%$ in saline, $0.1 \mathrm{ml} / 10 \mathrm{~g}$ body mass) was administered by i.p injections. Immediately after administration, each animal was placed inside a transparent Plexiglas box. The number of abdominal writhes accompanied by elongation of the body and stretching of the hindlimbs was counted for $30 \mathrm{~min}$. The experimental groups $(n=8$ each) were treated similarly to what was described for the tail-flick test.

Statistical Analysis. The Student's paired $t$-test was used for comparing the baseline and post-injection TLFs. Statistical comparisons among experimental groups were performed by one-way analysis of variance (ANOVA) followed by the Tukey test. The level of $P<0.05$ was taken as significant. Data are presented below as means \pm s.e.m.

\section{RESULTS}

Tail-Flick Test. Statistical analysis using the paired $t$-test revealed that i.p. injections of Valeriana

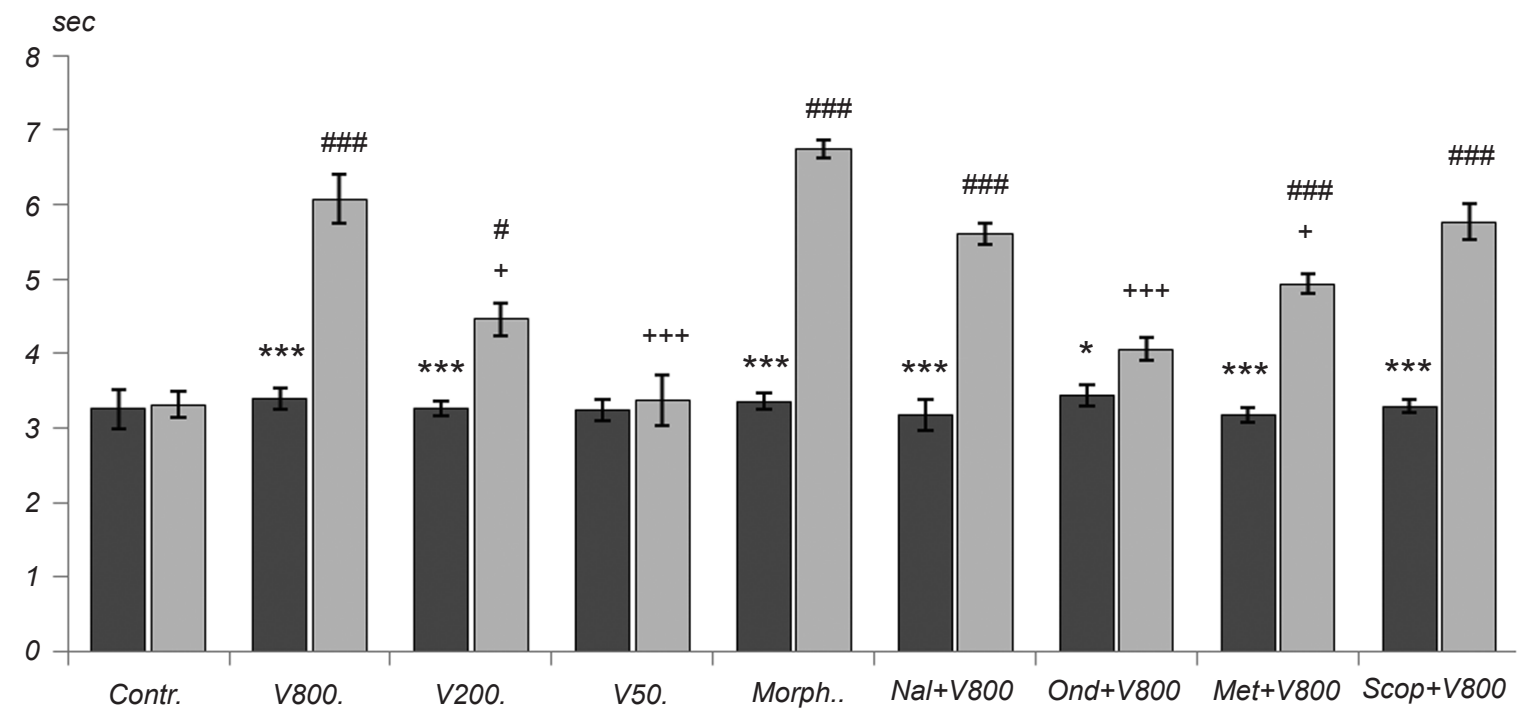

F i g. 1. Changes in the tail-flick latency (vertical scale, sec, before and after treatment) in experimental groups. The animals were divided into the following groups: control (Contr.), V800 (received $800 \mathrm{mg} / \mathrm{kg}$ of the extract of the Valeriana officinalis), V200 (200 mg/kg Valeriana), V50 (50 mg/kg Valeriana), Morph. (1.0 mg/kg morphine), Nal + V800 (naloxone and $800 \mathrm{mg} / \mathrm{kg}$ Valeriana), Ond + V800 (ondansetron and $800 \mathrm{mg} / \mathrm{kg}$ Valeriana), Met + V800 (metoclopramide and $800 \mathrm{mg} / \mathrm{kg}$ Valeriana), and Scop + V800 (scopolamine and $800 \mathrm{mg} / \mathrm{kg}$ Valeriana). ${ }^{*} P<0.05$ and ${ }^{* *} P<0.01$, cases of significant differences of post-injection values vs. pre-injection ones in the same group. ${ }^{\sharp} P<0.05$, ${ }^{\# \#} P<0.01$, and ${ }^{\# \# \#} P<0.001$, significantly different compared to the control group. ${ }^{+} P<0.05$, and ${ }^{++} P<0.001$, significantly different compared to the V800 group. Each column represents means \pm s.e.m.

Р и с. 1. Середні значення латентного періоду відсмикування хвоста (вертикальна шкала, с) в експериментальних групах перед уведенням тестованих агентів та після цього. 


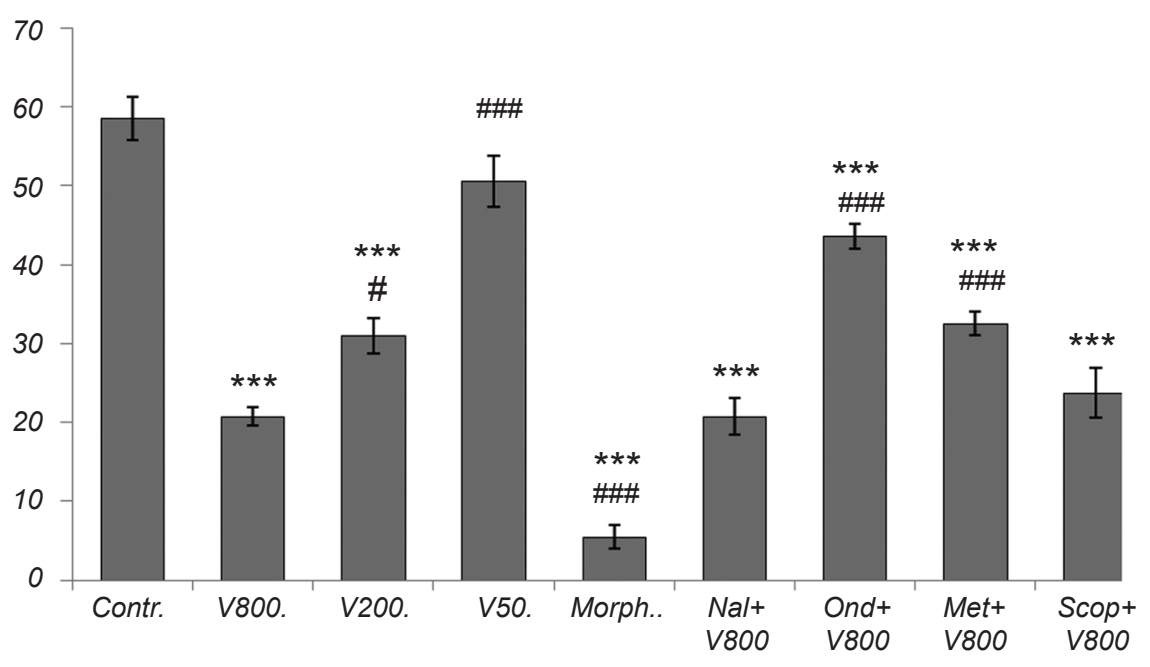

F i g. 2. The number of writhings (vertical scale) during $30 \mathrm{~min}$ in the acetic acid-induced writhing test. Experimental animals were divided into the following groups: control (Contr), V800 (received $800 \mathrm{mg} / \mathrm{kg}$ Valeriana), V200 (200 mg/kg Valeriana), V50 (50 mg/kg Valeriana), Morph. (1.0 mg/kg morphine), Nal + V800 (naloxone and $800 \mathrm{mg} / \mathrm{kg}$ Valeriana), Ond + V800 (ondansetron and $800 \mathrm{mg} / \mathrm{kg}$ Valeriana), Met + V800 (metoclopramide and $800 \mathrm{mg} / \mathrm{kg}$ Valeriana), and Scop + V800 (scopolamine and $800 \mathrm{mg} / \mathrm{kg}$ Valeriana $) .{ }^{*} P<0.05,{ }^{* *} P<0.01$ and ${ }^{* * *} P<0.001$, compared to the control group; ${ }^{\#} P<0.05,{ }^{\#} P<0.01$, and ${ }^{\# \#} P<0.001$, compared to the V800 group. Each column represents means \pm s.e.m.

P и с. 2. Кількість „корчів” у межах 30-хвилинного періоду спостереження (вертикальна шкала) в оцтовокислотному тесті (індукція вісцерального болю).

extract at doses of 200 and $800 \mathrm{mg} / \mathrm{kg}$ (but not of $50 \mathrm{mg} / \mathrm{kg})$, morphine, and Valeriana $(800 \mathrm{mg} / \mathrm{kg})$ with naloxone, ondansetron, metoclopramide, and scopolamine significantly increased the TFL, as compared with the pretreatment (Fig. 1). Comparison of the TFL using one-way ANOVA indicated that there were no significant differences between the experimental groups before treatment $(P>0.05)$, but the differences were highly significant after treatment $(P<0.0001)$. The Tukey post-hoc test showed that the TFL values showed no significant difference between the Valeriana $(800 \mathrm{mg} / \mathrm{kg})$ and morphine groups, Valeriana $(800 \mathrm{mg} / \mathrm{kg})+$ naloxone, and Valeriana $(800 \mathrm{mg} / \mathrm{kg})+$ + scopolamine. However, the TFL mean value in the Valeriana $(800 \mathrm{mg} / \mathrm{kg})$ group was significantly greater than TFLs in the groups that received 200 and $50 \mathrm{mg} / \mathrm{kg}$ of the Valeriana extract, Valeriana $(800 \mathrm{mg} / \mathrm{kg})+$ ondansetron, and Valeriana $(800 \mathrm{mg} / \mathrm{kg})+$ metoclopramide (Fig. 1).

Writhing Test. Statistical analysis by oneway ANOVA showed that there were significant differences in the number of writhings between animal groups $(P<0.0001)$. The Tukey posthoc test indicated that, except for the Valeriana $(50 \mathrm{mg} / \mathrm{kg})$ group, the numbers of writhings in other groups were significantly smaller than those in the control group. Also, there were no significant differences in the number of writhings between the mouse groups treated with Valeriana $(800 \mathrm{mg} / \mathrm{kg})$, Valeriana $(800 \mathrm{mg} / \mathrm{kg})+$ naloxone, and Valeriana $(800 \mathrm{mg} / \mathrm{kg})+$ scopolamine. However, the mean numbers of writhings in the two Valeriana-treated groups (50 and $200 \mathrm{mg} / \mathrm{kg}$ ),
$800 \mathrm{mg} / \mathrm{kg}$ Valeriana + ondansetron, and $800 \mathrm{mg} / \mathrm{kg}$ Valeriana + metoclopramide were significantly greater than those in mice that received only $800 \mathrm{mg} / \mathrm{kg}$ Valeriana (Fig. 2).

\section{DISCUSSION}

Progress in developing analgesic drugs has been rather significant in recent years, but the need for drugs with better effects remains. Herbal medicine and the use of medicinal plants is one of the main ways to meet this need, and more and more investigations are performed in this field.

Valeriana ofiicinalis in Eurasia and America, Valeriana wallichi in India, and Valeriana angustifolia in China and Japan are species of Valeriana that are extensively used for calming, sleep induction, and sedative effects in different nations. Valeriana decreases the general activity of the CNS via inhibiting GABA breakdown in particular $[9,12,15,16]$. Valeriana is also used for relieving anxiety and for insomnia [17-19].

To our knowledge, the analgesic effects of this plant have not been estimated directly until now. Results of our study show that the hydroalcoholic extract of Valeriana officinalis demonstrates significant dose-dependent antinociceptive effects. The highest $(800 \mathrm{mg} / \mathrm{kg})$ dose of the extract successfully reduced somatic pain, while a $50 \mathrm{mg} / \mathrm{kg}$ dose did not. Ondansetron, a serotonergic system antagonist, and metoclopramide, a dopaminergic system antagonist, significantly decreased the effect 
of the extract, showing that Valeriana blocked pain via its influence on the respective pathways. We can say that ondansetron exerted a more intense blocking effect compared to that of metoclopramide. We found no significant difference between the animal groups treated with Valeriana $(800 \mathrm{mg} / \mathrm{kg})$, Valeriana $(800 \mathrm{mg} / \mathrm{kg})+$ naloxone, and Valeriana $(800 \mathrm{mg} / \mathrm{kg})+$ + scopolamine, indicating that the antinociception effect of the extract is preserved, and that the opioidergic and cholinergic systems are probably not involved so significantly in the induction of antinociceptic effects of the Valeriana extract.

The antinociceptive activity was also clearly expressed as significant reduction in the number of abdominal writhings when compared to that in control animals. In this test, we obtained results comparable with those in the tail-flick test. The numbers if withings were reduced with increase in the dose of the extract; thus, the dose dependence of the Valeriana hydroalcoholic extract was also quite clear. In this test, ondansetron and metoclopramide also antagonized the effects of the extract.

Valeriana may affect the CNS by interaction with the serotonin, GABA, melatonin, or adenosine systems [20]. Long-term treatment with Valeraiana officinalis exerted no effect on the reduction of dopamine uptake in the striatum of Wistar rats [10]. Aqueous and methanolic extracts of Valeriana adscendens (one of the Valeriana species) showed affinity with respect to $\mathrm{D}_{1}$ and $5-\mathrm{HT}_{1 \mathrm{~A}}$ receptors, while no affinity with respect to noradrenergic receptors has been reported [21]. 6-Methylapigenin is a flavonoid detected in Valeriana officinalis. This flavone is a ligand for a benzodiazepine binding site in $\mathrm{GABA}_{\mathrm{A}}$ receptors and was reported to cause anxiolytic effects in mice [22]. A flavonoid, 1-hydroxypinoresinol, derived from Valeriana officinalis, is a ligand for $5-\mathrm{HT}_{1 \mathrm{~A}}$ receptors [23]; these receptors were found to be involved, with high efficacy, in the central analgesia mechanism [24, 25]. Hesperidin, a flavonone glycoside, was found to be present in Valeriana [11], and it was reported that linarin, another flavonone glycoside, was also found in this plant [26]. Clear sedation [27] and antinociception [28] effects of hesperidin have been reported earlier.

Thus, the antinociception effects of Valeriana officinalis have been assessed quite obviously. These effects are significantly antagonized by ondansetron and metoclopramide. Naloxone and scopolamine exerted much smaller influences on the Valeriana hypoalgezic effects in the tail-flick and writhing tests. We can conclude that the antinociception effects of this remedy are mediated by the serotonergic and dopaminergic systems, and flavonoids affect the latter. These pathways have not been reported for the Valeriana officinalis effects earlier, and our results may serve as a motivation for further investigations in this field.

All procedures for the humane treatment of animals were approved by the Research Committee of the Hamadan University of Medical Sciences and were performed according to the Guide for Care and Use of Laboratory Animals published by the United States National Institutes of Health (NIH Publication No. 85-23, revised 1985).

The authors, S. Shahidi, A. Bathaei, and P. Pahlevani, have no conflict of interest.

This work was financially supported by a grant from the Hamadan University of Medical Sciences.

\section{C. Шахіді ${ }^{1}$, A. Батхаєї ${ }^{1}$, П. Пахлевані ${ }^{1,2}$}

\section{АНТИНОЦИЦЕПТИВНІ ЕФЕКТИ ЕКСТРАКТУ}

ВАЛЕРІАНИ В ЕКСПЕРИМЕНТАХ НА МИШАХ: ЗАЛУЧЕННЯ ДОФАМІН- ТА СЕРОТОНІНЕРГІЧНОЇ СИСТЕМ

\begin{abstract}
${ }^{1}$ Нейрофізіологічний дослідницький центр Хамаданського медичного університету (Іран).
\end{abstract}

${ }^{2}$ Хамаданський медичний університет (Іран).

\section{Р е 3 ю м е}

Валеріана лікувальна (Valeriana officinalis) широко використовується як рослинний лікувальний засіб у традиційній медицині. Достовірні відомості про можливу антиноцицептивну дію цієї рослини, проте, були відсутні. Ціллю нашого дослідження було оцінити в експериментах на мишах, чи здатний водноспиртовий екстракт валеріани модулювати біль, а також з'ясувати можливі механізми таких ефектів. Дорослі самці мишей лінії Balb/c були рандомізовано поділені на дев'ять груп. Їм внутрішньоочеревинно ін'єкували фізіологічний розчин, водноспиртовий екстракт 3 коренів валеріани (800, 200 або 50 мг сухої речовини на 1 кг маси), морфін, а в чотирьох групах - комбінації 800 мг/кг екстракту валеріани з антагоністами систем, залучених у реалізацію антиноцицептивних ефектів, - налоксоном, ондасетроном, метоклопрамідом або скополаміном. Для оцінки можливої модуляції болю використовували тест відсмикування хвоста та оцтовокислотний тест „корчів”. Латентні періоди відсмикування хвоста в групах, що отримували 800 та 200 (але не 50) мг екстракту та комбіновані ін'єкції 800 мг/кг валеріани із вказаними блокаторами, були довшими, ніж у групі контролю. В той же час латентні періоди цієї реакції в групах 800 мг/кг екстракту + ондасетрон та метоксипрамід були вірогідно меншими, ніж при ізольованій дії 800 мг/кг екстракту. Кількість „корчів” у мишей у межах періоду 
спостереження у відповідному тесті після ін'єкції екстракту була меншою, ніж у контролі. Число таких „корчів” у групах 800 мг/кг екстракту в комбінаціях із ондасетроном та метоклопрамідом було вірогідно більшим порівняно з тим, що спостерігалось у разі дії лише екстракту в аналогічної кількості. Зроблено висновок, що екстракт валеріани здійснює очевидний аналгетичний вплив, опосередкований серотонін- та дофамінергічною системами.

\section{REFERENCES}

1. J. B. Calixto, A. Beirith, J. Ferreira, et al., "Naturally occurring antinociceptive substances from plants," Phytother. Res., 14, No. 6, 401-418 (2000).

2. M. A. O'Hara, D. Kiefer, K. Farrell, and K. Kemper, "A review of 12 commonly used medicinal herbs," Arch. Fam. Med., 7, No. 6, 523-536 (1998).

3. C. S. Yuan, S. Mehendale, Y. Xiao, et al., "The gammaaminobutyric acidergic effects of valerian and valerenic acid on rat brainstem neuronal activity," Anesth. Analg., 98, No. 2, 353-358 (2004).

4. C. Stevinson and E. Ernst, "Valerian for insomnia: a systematic review of randomized clinical trials," Sleep Med., 1, No. 2, 91 99 (2000)

5. L. M. Del Valle-Mojica, J. M. Cordero-Hernández, G. González-Medina, et al., "Aqueous and ethanolic Valeriana officinalis extracts change the binding of ligands to glutamate receptors," Evid.-Based Complement. Alternat. Med., Article ID 891819, 7 pages (2011).

6. S. Hadley and J. J. Petry, "Valerian," Am. Fam. Physic., 67, No. 8, 1755-1758 (2003).

7. J. O. Malva, S. Santos, and T. Macedo, "Neuroprotective properties of Valeriana officinalis extracts," Neurotox. Res., 6 , No. 2, 131-140 (2004).

8. A. Diaper and I. Hindmarch, "A double-blind, placebocontrolled investigation of the effects of two doses of a valerian preparation on the sleep, cognitive and psychomotor functions of sleep-disturbed older adults," Phytother. Res., 18, No. 10, 831-836 (2004).

9. S. Bent, A. Padula, D. Moore, et al., "Valerian for sleep: a systematic review and meta-analysis," Am. J. Med., 119, No. 12, 1005-1012 (2006).

10. R. Fachinetto, J. G. Villarinho, C. Wagner, et al., “Valeriana officinalis does not alter the orofacial dyskinesia induced by haloperidol in rats: role of dopamine transporter," Prog. Neuropsychopharmacol. Biol. Psychiat., 31, No. 7, 1478-1486 (2007).

11. M. Marder, H. Viola, C. Wasowski, et al., "6-Methylapigenin and hesperidin: new valeriana flavonoids with activity on the CNS," Pharmacol. Biochem. Behav., 75, No. 3, 537-545 (2003).

12. P. J. Houghton, "The scientific basis for the reputed activity of Valerian,” J. Pharm. Pharmacol., 51, No. 5, 505-512 (1999).

13. E. M. Choi, "Antinociceptive and antiinflammatory activities of pine (Pinus densiflora) pollen extract," Phytother. Res., 21, No. 5, 471-475 (2007).

14. S. R. Mada, M. R. Metukuri, L. Burugula, et al., "Antiinflammatory and antinociceptive activities of gossypin and procumbentin-cyclooxygenase-2 (COX-2) inhibition studies," Phytother. Res., 23, No. 6, 878-884 (2009).

15. S. McCabe, "Complimentary herbal and alternative drugs in clinical practice," Perspect. Psychiat. Care, 38, No. 3, 98-107 (2002).

16. P. Morazzoni and E. Bombardelli, "Valeriana offcinalis: traditional use and recent evaluation of activity," Fitoterapia, 66, 99-112 (1995).

17. R. Della Loggia, A. Tubaro, and C. Redaelli, "Evaluation of the activity on the mouse CNS of several plant extracts and a combination of them," Rev. Neurol., 51, 297-310 (1981).

18. D. Kennedy, W. Little, C. Haskell, and A. Scholey, “Anxiolytic effects of a combination of Melissa officinalis and Valeriana officinalis during laboratory induced stress," Phytother. Res., 20, 96-102 (2006).

19. I. Oliva, M. Gonzalez-Trujano, J. Arrieta, et al., "Neuropharmacological profile of hydroalcohol extract of Valeriana edulis ssp. procera roots in mice," Phytother. Res., 18, 290-296 (2004).

20. E. Abourashed, U. Koetter, and A. Brattstrom, "In vitro binding experiments with Valerian hops, and their fixed combination extract (Ze91019) to selected central nervous system receptors," Phytomedicine, 11, 633-638 (2004).

21. C. Nencini, F. Cavallo, A. Capasso, et al., "Binding studies for serotoninergic, dopaminergic, and noradrenergic receptors of Valeriana adscendens Trel. extracts," J. Ethnopharmacol., 108, No. 2, 185-187 (2006).

22. C. Wasowski, M. Marder, H. Viola, et al., "Isolation and identification of 6-methylapigenin, a competitive ligand for the brain GABA(A) receptors, from Valeriana wallichii D.C.," Planta Med., 68, 934-936 (2002).

23. U. Bodesheim and J. Hölzl, "Isolierung, Strukturaufklärung und Radioreceptorassays von Alkaloiden und Lignan aus Valeriana officinalis L.," Pharmazie, 52, 386-391 (1997).

24. L. Bardin, J. P. Tarayre, N. Malfetes, et al., "Profound, nonopioid analgesia produced by the high-efficacy 5-HT(1A) agonist F 13640 in the formalin model of tonic nociceptive pain," Pharmacology, 67, 182-194 (2003).

25. F. C. Colpaert, J. P. Tarayre, W. Koek, et al., "Large-amplitude 5-HT1A receptor activation: a new mechanism of profound central analgesia," Neuropharmacology, 43, No., 945-958 (2002).

26. S. Fernandez, C. Wasowski, A. C. Paladini, and M. Marder, "Sedative and sleep-enhancing properties of linarin, a flavonoid isolated from Valeriana officinalis," Pharmacol. Biochem. Behav., 77, No. 2, 399-404 (2004).

27. S. L. Guzmán-Gutiérrez and A. Navarrete, "Pharmacological exploration of the sedative mechanism of hesperidin identified as the active principle of Citrus sinensis flowers," Planta Med., No. 75, 295-301 (2009).

28. A. L. Martinez, M. E. González-Trujano, M. Chávez, et al., "Hesperidin produces antinociceptive response and synergistic interaction with ketorolac in an arthritic gout-type pain in rats," Pharmacol. Biochem. Behav., 97, No. 4, 683-689 (2010). 